\title{
Numerical method of vibroacoustic estimators analysis in a frequency domain for IC engine
}

\begin{abstract}
The paper describes the assessment of the main processes taking place in a IC engine. The article concerns vibroacoustic processes. Authors chosen vibration ones to the research. In view of the characteristics that the above processes have for the diagnosis of the slow and fast processes taking place during combustion, it was necessary to take into account them for periodic and on-line analyses of technical state and correctness of the engine dynamic processes run. Evaluations of the possibility of the method application were performed in the point of view of the diagnostic analysis and its use in the diagnostic system for combustion process and in the aspect of the limitation of excessive emission sources (occurred by incorrect processes runs or by functional characteristics decrease of the object or by potential failures of the elements and subassemblies during exploitation). Method analysis of vibration acceleration generated in an engine, basing on diagnostics theory use, with the help of which quantitive components obtained from the frequency-domain processes runs were searched. Diagnostic estimators were the measures of the quantity assessment, changes of which were the subject of presented analyses. Limits and qualification guidelines of an incorrect process are also in a paper. Diagnostic algorithms of misfire detection for the present and future vehicles combustion engines (also for hybrid vehicles) and in the aspect of OBD III or OBM systems application are taken into account.
\end{abstract}

Keywords: common rail diesel engine, vibroacoustics, OBD system, environment protection, digital signal processing, combustion, diagnostic algorithm

\section{Metoda numeryczna analizy estymatorów wibroakustycznych w dziedzinie częstotliwości dla silnika spalinowego}

\begin{abstract}
$W$ artykule przedstawiono ocenę przebiegu procesów roboczych zachodzacych w silniku spalinowym. Praca dotyczy procesów wibroakustycznych, z których do badań wybrano procesy drganiowe. Analizując właściwości powyższych procesów z punktu widzenia diagnostyki procesów wolno- $i$ szybkozmiennych zachodzacych podczas spalania paliwa, konieczne stało się uwzględnienie ich w ocenie okresowej i ciagłej stanu technicznego obiektu i poprawności procesów zachodzacych w tymże silniku. Ocenę możliwości zastosowania metody przeprowadzono pod katem analizy diagnostycznej i jej aplikacji w systemie diagnostycznym procesu spalania oraz w aspekcie ograniczenia nadmiernej emisji przez źródta napędu pojazdu (wynikające z nieprawidłowości przebiegu procesów lub zmniejszenia charakterystyk funkcjonalnych obiektu, albo potencjalnych niesprawności elementów i podzespołów w procesie eksploatacji). Dokonano analizy metody bazującej na zastosowaniu przyspieszeń drgań generowanych $w$ silniku, z zastosowaniem teorii diagnostycznej, oraz ilościowych składowych uzyskanych z przebiegów procesów przedstawionych $w$ dziedzinie częstotliwości. Estymatory diagnostyczne stanowity ilościowe elementy procesu oceny, których przedmiotem byly ich ilościowe zmiany. Przedstawiono wartości graniczne i wytyczne kwalifikacji nieprawidłowości zachodzacych w procesie. Uwzględniono ponadto algorytmy diagnostyczne wykrycia wypadania zapłonów dla obecnych i przyszłych konstrukcji silników stosowanych w pojazdach (również dla silników o napędzie hybrydowym) i w aspekcie zastosowania systemów OBDIII i OBM.
\end{abstract}

Słowa kluczowe: silnik spalinowy ZS o systemie zasilania typu common rail, wibroakustyka, system OBD, ochrona środowiska naturalnego, cyfrowa obróbka sygnatów, spalanie, algorytm diagnostyczny

\section{Introduction}

Signal estimation concerns the assessment of the specified features, among which can be point features (feature value is one number) or function features (feature value is a time or frequency function).

Spectral power density is the basic functional signal feature obtained in the frequency domain. Methods of its allotment are based on the Fourier theory, according to which each signal can be described as a linear combination of the harmonic functions. Signal discreet values observation is done in the finite time section, what means that above signal is observed with the help of the window function, whose Fourier transform is named a window

\section{Wprowadzenie}

Ocena sygnału dotyczy wyznaczenia jego określonych cech, wśród których można wymienić cechy punktowe (wartość cechy jest w postaci jednej liczby) lub funkcyjne (wartość cechy jest opisana funkcją czasu lub częstotliwości).

Widmowa gęstość mocy stanowi podstawową cechę funkcyjną sygnału uzyskaną w dziedzinie częstotliwości. Metody jej wyznaczania są oparte na wykorzystaniu teorii Fouriera, zgodnie z którą każdy sygnał można opisać liniową kombinacją funkcji harmonicznych. Obserwacji wartości sygnału dyskretnego dokonuje się w skończonym przedziale czasu, co oznacza, iż powyższy sygnał jest poddany obserwacji z zastosowaniem funkcji okna, którego przekształcenie 
in the frequency domain $[1,2,4]$. The outcomes of such transformation are the amplitude, phase, energetic and power density spectra.

Most machines and devices operate with the cyclic working movement, so one can state, that generated vibroacoustic process is also periodic. Technical state of the object is assessed on the basis of the analysis of the deviations from the processes periodicity. When the processes taking place in a machine run improperly or the failure connected with the faster wear appears, it is possible to use a spectral analysis and link together with the object kinematics. Detection of the irregularities in the process or malfunctions in the technical object is a process of the diagnostic signal generation on the basis of the process variables. The analysis of the vibrations that are generated by the engine, in the range of a single engine working cycle, we can state that it is a process changing in time, both in the amplitude and frequency domains, as a result of subsequent engine work phases.

Searching for the specified failure or malfunction in the dynamic process for internal combustion engines require to use accurate post processing methods of the signal analysis, that will be helpful to assess the technical engine state and irregularities in engines operation precisely. That is why the FFT analysis [1-4] should be also used parallel with time and amplitude domain assessments of the research diagnostic signals. In the result, the required research and post processing signal analysis were considered in the paper and done for a modern compression-ignition 4-stroke engine used in the LDV vehicles.

\section{Research IC engine technical data}

The authors performed the specified research of combustion process in the point of view of the on-line diagnosis of the such process and its lack. The paper considers research,
Fouriera nosi nazwę okna w dziedzinie częstotliwości [1, $2,4]$. W wyniku takiego przekształcenia powstają widma amplitudowe, fazowe, energetyczne i gęstości mocy.

Dla większości maszyn i urządzeń ich praca i realizowany ruch roboczy ma charakter cykliczny, dzięki czemu wygenerowany proces wibroakustyczny jest również okresowy. Stan techniczny obiektu jest określany na podstawie analizy odchyleń od okresowości procesów. Jeżeli procesy zachodzące w maszynie przebiegają nieprawidłowo, lub pojawia się niesprawność wynikająca z szybszego zużycia, możliwe jest zastosowanie analizy widmowej i połączenie jej z kinematyką obiektu technicznego. Wykrycie nieregularności w procesie lub niesprawności w obiekcie technicznym jest procesem generacji sygnału diagnostycznego na podstawie zmiennych procesu. Analizę drgań powstających w silniku, w ramach pojedynczego cyklu roboczego, można określić jako zmiany procesu w dziedzinie amplitudy i częstotliwości, będące wynikiem następujących po sobie faz pracy silnika.

Poszukując określonego uszkodzenia lub niesprawności w procesie dynamicznym zachodzącym w silniku spalinowym, niezbędne jest zastosowanie dokładnych metod przetwarzania sygnału, pomocnych w precyzyjnej ocenie stanu technicznego silnika i nieregularności występujących w jego pracy. Z tego względu celowe jest zastosowanie analizy FFT (Fast Fourier Transform) [1-4], równolegle z oceną czasową i częstotliwościową sygnałów diagnostycznych. W związku $\mathrm{z}$ tym $\mathrm{w}$ ramach pracy przeprowadzono niezbędne badania i analizę sygnału dla nowoczesnego, 4-suwowego silnika o zapłonie samoczynnym (ZS), stosowanego w pojazdach typu LDV (Light Duty Vehicle).

\section{Dane techniczne badanego silnika spalinowego}

Przeprowadzono badania procesu spalania z punktu widzenia ciągłej diagnostyki powyższego procesu i wykry-

Table 1. The technical data of a research engine [9]

Tabela 1. Dane techniczne badanego silnika [9]

\begin{tabular}{|c|c|}
\hline Data type/rodzaj parametru & Data value/wartość \\
\hline Engine type/rodzaj silnika & $\begin{array}{l}\text { 1.3 JTD common rail CI engine with direct injection } / 1.3 \mathrm{JTD} \text {, silnik } \\
\text { ZS z bezpośrednim wtryskiem paliwa typu common rail }\end{array}$ \\
\hline Number of cylinders/liczba cylindrów & 4, in-line/uktad rzędowy \\
\hline Engine displacement/objętość skokowa silnika $\left[\mathrm{cm}^{3}\right]$ & 1251 \\
\hline Bore x stroke/średnica tłoka x skok tłoka [mm] & $69.6 \times 82.0$ \\
\hline Cylinder head system/liczba zaworów/1 cylinder & 4 valves per cylinder \\
\hline Timing system/układ rozrządu & $\begin{array}{c}2 \text { overhead camshafts, fingertip rockers, chain drive/2 wałki rozrządu } \\
\text { w głowicy, napęd dźwigienkowy, tańcuchowy }\end{array}$ \\
\hline Crankcase/skrzynia korbowa & cast iron with aluminium base/odlew żeliwny z podstawa aluminiowa \\
\hline Injection system/injection pressure/system wtrysku/ciśnienie wtrysku [MPa] & Common rail, Multijet/140 MPa \\
\hline Turbocharger/turbosprężarka & Fixed geometry/o stałej geometrii lopatek \\
\hline Nominal brake effective power/znamionowa moc użyteczna $[\mathrm{kW}]$ & $55($ for $\mathrm{n}=4000 \mathrm{rpm})$ \\
\hline Torque/moment obrotowy $[\mathrm{N} \cdot \mathrm{m}]$ & $170($ for $\mathrm{n}=1750-2500 \mathrm{rpm})$ \\
\hline Compression ratio/stopień sprężania & $18.1: 1$ \\
\hline $\begin{array}{l}\text { Dimensions }[\mathrm{m}]: \text { length/width/height/wymiary }[\mathrm{m}] \text { : dlugość/szerokośćl } \\
\text { wysokość }\end{array}$ & $0.46 / 0.50 / 0.65$ \\
\hline $\mathrm{CO}_{2}$ emission/emisja $[\mathrm{g} / \mathrm{km}]$ & 113 \\
\hline Average fuel consumption/ średnie zużycie paliwa $\left[\mathrm{dm}^{3} / 100 \mathrm{~km}\right]$ & 4.24 \\
\hline
\end{tabular}


which was conducted on an common rail 4-stroke compression-ignition engine used in LDV vehicles (Fig. 1, tab. 1).

\section{Research test stand and measurement conditions}

All authors measurements were performed for the engine test stand conditions, and working points of the engine were chosen from the engine speed and torque operating ranges (Fig. 2, tab. 4).

The placement of the vibration acceleration transducer (Bruel\&Kjær 4504A) was located on the engine block, nearby the generated dynamic combustion processes. Measurements were done for 3 perpendicular dimensions (Fig. 3, tab. 2) with the use of the Bruel\&Kjær Pulse 3560-C system (tab. 3).

Table. 2. Technical data of a Bruel\&Kjær 4504A piezoelectric accelerometer used in the research [6]

Tabela. 2. Dane techniczne przetwornika przyspieszeń drgań Bruel\&Kjar 4504A zastosowanego w badaniach [6]

\begin{tabular}{|c|c|}
\hline $\begin{array}{l}\text { Bruel\&Kjær 4504A piezoelectric accelerometer/ } \\
\text { piezoelektryczny przetwornik przyspieszeń drgań } \\
\text { Bruel\&Kjar } 4504 \mathrm{~A}\end{array}$ & \\
\hline Frequency/częstotliwość [Hz] & $1-10000$ \\
\hline Senitivity/czułość $[\mathrm{mV} / \mathrm{g}]$ & 10 \\
\hline Temperature range/zakres temp. $\left[{ }^{\circ} \mathrm{C}\right]$ & $-50-125$ \\
\hline $\begin{array}{l}\text { Residual noise level in Spec. Freq. Range/ } \\
\text { szczątkowy poziom szumu dla określonego } \\
\text { zakresu częstotliwości (RMS) [mg] }\end{array}$ & \pm 0.4 \\
\hline $\begin{array}{l}\text { Maximum operational/shock level/maksymal- } \\
\text { ny poziom użyteczny/udarowy (szczytowy) }[\mathrm{g}] \\
\text { (peak) }\end{array}$ & $\pm 750 / \pm 3000$ \\
\hline Weight/masa $[\mathrm{g}]$ & 15 \\
\hline Output/rodzaj wyjścia & CCLD \\
\hline $\begin{array}{l}\text { Resonance frequency/częstotliwość rezonanso- } \\
w a[\mathrm{kHz}]\end{array}$ & 50 \\
\hline $\begin{array}{l}\text { Triaxial/TEDS/Electrical connector/trójosiowy/ } \\
\text { TEDS/złacze elektryczne }\end{array}$ & $\begin{array}{c}\mathrm{Yes} / \text { tak/No/nie } \\
10-32 \mathrm{UNF}\end{array}$ \\
\hline
\end{tabular}

The following dimensional point measures were taken into consideration in the research analyses [6-9]:

a) mean value

$$
u_{\text {sr }}=u_{\text {sr }}(\theta)=\frac{1}{T} \int_{0}^{T} \mid u(t, \theta) d t
$$

b) RMS value

$$
\mathrm{u}_{\mathrm{sk}}=\mathrm{u}_{\mathrm{sk}}(\theta)=\left[\frac{1}{\mathrm{~T}} \int_{0}^{\mathrm{T}} \mathrm{u}^{2}(\mathrm{t}, \theta) \mathrm{dt}\right]^{1 / 2}
$$

c) peak value

$$
\mathrm{u}_{\mathrm{sz}}=\mathbf{u}_{\mathrm{sZ}}(\theta)=\mathrm{E}\{\underset{0<\mathrm{t}<\mathrm{T}}{\operatorname{Max}} \mid \mathrm{u}(\mathrm{t}, \theta)\}
$$

cia jego braku. Praca dotyczy badań przeprowadzonych na 4-suwowym silniku ZS z zasobnikowym systemem zasilania paliwem (typu common rail), stosowanym w pojazdach typu LDV (rys. 1, tab. 1). a)

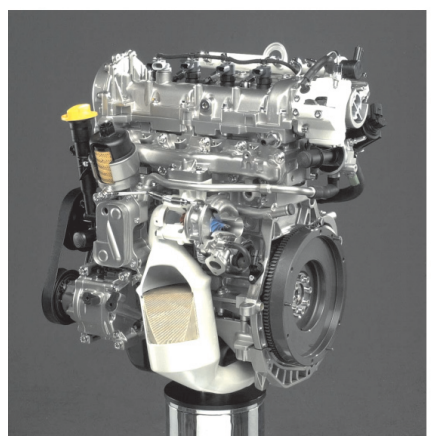

b)

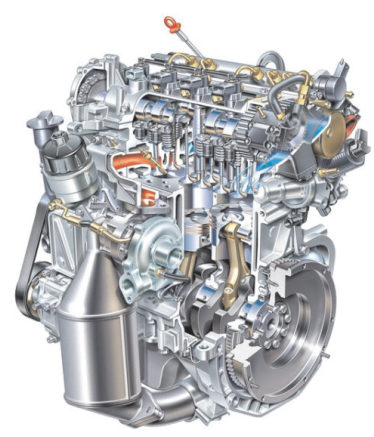

Fig. 1. The view (a) and a cross-section (b) of Fiat 1.3 JTD engine $[1,2]$ Rys. 1. Widok (a) i przekrój poprzeczny (b) silnika Fiat 1.3 JTD [1, 2]

\section{Stanowisko badawcze i warunki pomiarów}

Wszystkie pomiary przeprowadzono w warunkach hamowni silnikowej, a punkty pracy silnika wybrano z użytecznego zakresu prędkości obrotowej i momentu obrotowego (rys. 2, tab. 4).

a)

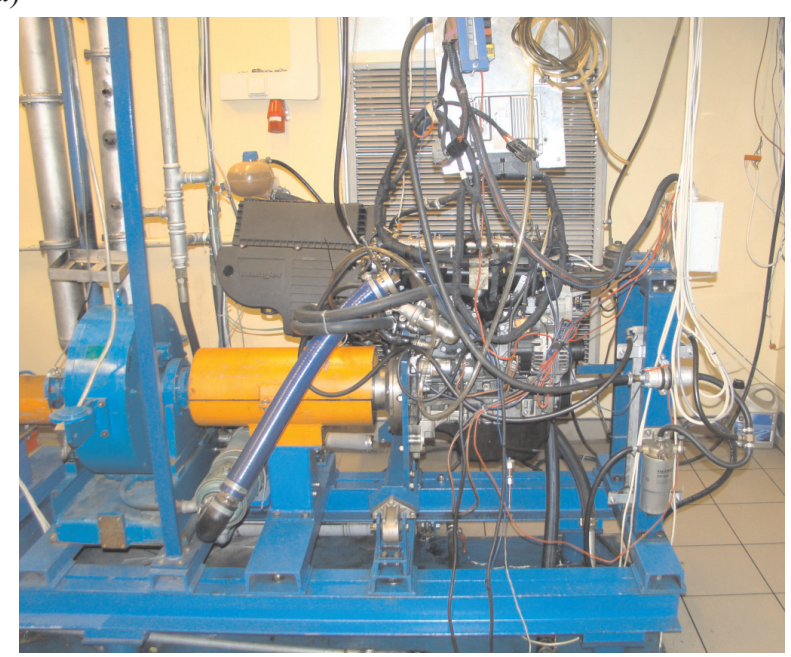

b)

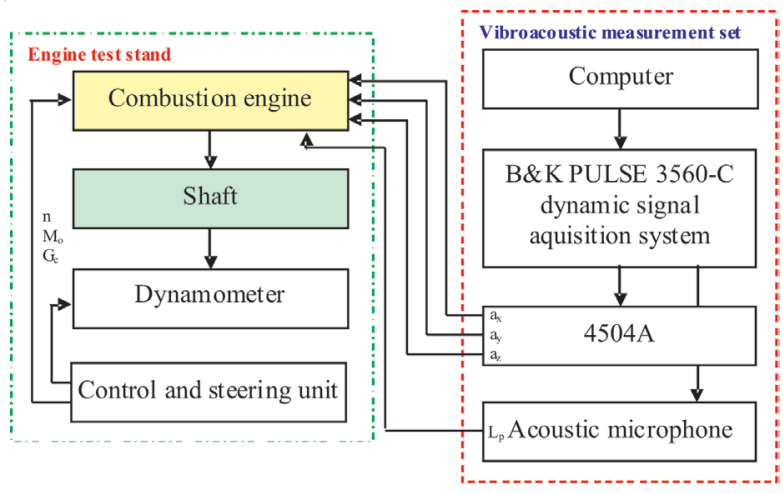

Fig. 2. The view (a) and functional scheme (b) of the measurement test stand

Rys. 2. Widok (a) i schemat funkcjonalny (b) stanowiska pomiarowego 
Table 3. Technical data of a Bruel\&Kjær Pulse 3560-C measurement system [6]

Tabela 3. Dane techniczne systemu pomiarowego Bruel

\begin{tabular}{|c|c|}
\hline Bruel\&Kjær Pulse 3560-C system & \\
\hline $\begin{array}{l}\text { Number of parallel input/output channels/liczba } \\
\text { równoległych kanałów wejściowych/wyjściowych }\end{array}$ & $5 / 1$ \\
\hline $\begin{array}{l}\text { Number of aux.channels/liczba kanałów dodatko- } \\
\text { wych (typu aux.) }\end{array}$ & 16 \\
\hline $\begin{array}{l}\text { Type of an input channels/rodzaj kanatów wej- } \\
\text { ściowych }\end{array}$ & $\begin{array}{l}\text { Direct/bezpośred- } \\
\text { ni, CCLD }\end{array}$ \\
\hline Frequency range/zakres częstotliwości [Hz] & $0-25600$ \\
\hline $\begin{array}{l}\text { Absolute Amplitude Precision (1 kHz, } 1 \mathrm{~V} \text { input }) / \\
\text { bezwzględna dokładność amplitudy (1 kHz, } 1 \mathrm{~V} \\
\text { wejście) }\end{array}$ & $\begin{array}{l} \pm 0.05 \mathrm{~dB}, \text { typical/ } \\
\text { typowy } \pm 0.01 \mathrm{~dB}\end{array}$ \\
\hline $\begin{array}{l}\text { Absolute maximum input/maksymalna wartość } \\
\text { bezwzględna sygnału na wejściu [Vpeak] }\end{array}$ & \pm 35 \\
\hline $\mathrm{A} / \mathrm{D}$ conversion/konwersja & $2 \times 24$ bits \\
\hline Voltage/napięcie [V (DC)] & $10-32$ \\
\hline $\begin{array}{l}\text { Nominal/max power consumption/ znamionowel } \\
\text { maksymalne zużycie energii }[\mathrm{W}]\end{array}$ & $30 / 42$ \\
\hline $\begin{array}{l}\text { Dimensions: height/width/depth/wymiary: wyso- } \\
\text { kość/szerokość/głębokość [m] }\end{array}$ & $0.105 / 0.376 / 0.300$ \\
\hline
\end{tabular}

d) peak-to-peak value

$$
\mathrm{u}_{\mathrm{rozst}}=\mathrm{u}_{\mathrm{rozst}}(\theta)=\left|\mathrm{u}_{\max }-\mathrm{u}_{\min }\right|
$$

Measurements were done in the following research conditions:

- termodynamic ambient conditions at the engine test stand area: $\mathrm{t}_{\mathrm{o}}=15^{\circ} \mathrm{C}$ and $\mathrm{p}_{\mathrm{o}}=1013 \mathrm{hPa}$,

- engine work conditions: stationary, for each constant engine speed values and for constant torque ( 7 engine speed values from the range $750-3000 \mathrm{rpm}$ ),

- vibroacoustic measurement conditions: Lp in the range 14.6-146 dB (frequency range: 16-20000 Hz, temperature: -30 to $+150{ }^{\circ} \mathrm{C}$ ), vibration acceleration frequency range: $1-10000 \mathrm{~Hz}$, sampling rate: $25.6 \mathrm{kHz}$,

- placement of a vibration transducer: on the engine block (measurement in the 3 perpendicular dimensions), microphone placement - perpendicularly to the engine surface.

The measurement signals were fed to the analog inputs of the data acquisition card. Measurement signals were filtered inside the card with the help of analog and digital filters and then were converted from analog to digital. The signals obtained in the data acquisition card in a digital form were stored in a computer memory. The recorded all time history courses of the measurement signals were subjected to the time selection process. In the above selection all recorded signals were divided into signal sequences including single working cycles of the internal combustion engine.

\section{Digital signal analysis}

The first part of the measurement signal analysis was to define the specific sections of the whole signal time runs a)

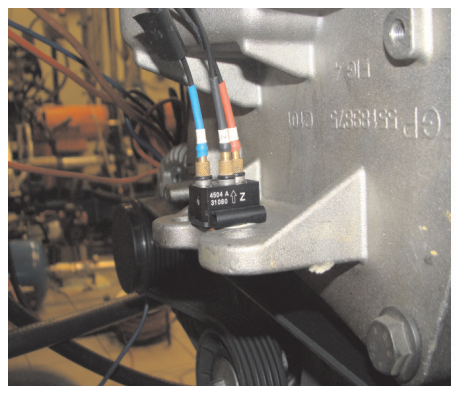

b)

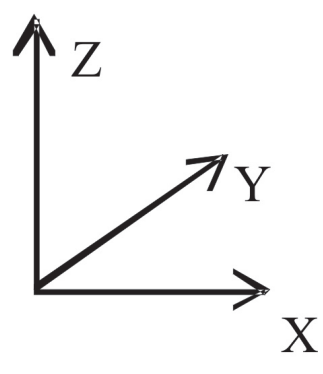

Fig. 3. The view of the vibration transducer placement on the engine (a) and measurement dimensions scheme (b)

Rys. 3. Widok mocowania przetwornika drgań do silnika (a) oraz schemat kierunków pomiarowych (b)

Table 4. Technical specification of the AMX210/100 dynamometer [5] Tabela 4. Specyfikacja techniczna hamulca AMX210/100 [5]

\begin{tabular}{|l|c|}
\hline AMX-210/100 & 100 \\
\hline Max power/maksymalna moc $[\mathrm{kW}]$ & 10000 \\
\hline Max speed/maksymalna prędkość $[\mathrm{rpm}]$ & 240 \\
\hline Max torque/maksymalny moment $[\mathrm{N} \cdot \mathrm{m}]$ & 200 \\
\hline Weight/masa $[\mathrm{kg}]$ & \\
\hline
\end{tabular}

Miejsce mocowania przetwornika przyspieszeń drgań (Bruel\&Kjær 4504A) zlokalizowano na kadłubie silnika, w pobliżu miejsca generacji procesów spalania. Pomiary przeprowadzono dla 3 wzajemnie prostopadłych kierunków (rys. 3, tab. 2) z zastosowaniem systemu Bruel\&Kjær Pulse (tab. 3).

W ramach analiz sygnałów uzyskanych z przeprowadzonych badań brano pod uwagę następujące wymiarowe miary punktowe [6-9]:

a) wartość średnią - wzór (1),

b) wartość skuteczną - wzór (2),

c) wartość szczytową - wzór (3),

d) wartość międzyszczytową - wzór (4).

Badania przeprowadzono w następujących warunkach:

- warunki termodynamiczne otoczenia na hamowni silnikowej: $\mathrm{t}_{\mathrm{o}}=15^{\circ} \mathrm{C}$ i $\mathrm{p}_{\mathrm{o}}=1013 \mathrm{hPa}$,

- warunki pracy silnika: stacjonarne, dla każdej stałej wartości prędkości obrotowej silnika i momentu obrotowego (7 wartości prędkości obrotowej z zakresu 750-3000 obr/min),

- warunki pomiarów wibroakustycznych: Lp w zakresie 14,6-146 dB (zakres częstotliwości: 16-20000 Hz, temperatura: -30 do $+150{ }^{\circ} \mathrm{C}$ ), zakres częstotliwości przyspieszeń drgań: 1-10000 Hz, częstotliwość próbkowania: $25,6 \mathrm{kHz}$

- miejsce mocowania przetwornika drgań: na kadłubie silnika (pomiar w 3 prostopadłych kierunkach), umieszczenie mikrofonu akustycznego - prostopadle do powierzchni silnika.

Sygnały pomiarowe były kierowane na wejścia analogowe karty do dynamicznej akwizycji danych. Wewnątrz niej podlegały procesowi filtracji z zastosowaniem filtrów 
that are connected with the defined groups of the engine dynamic processes. Then, such obtained signal runs were divided into sections that are of the specified process. The combustion process section were, after time-domain signal analysis, taken to the amplitude-domain analysis, in which were chosen the diagnostic dimension and point estimators which reflect the most important diagnostic information on the process.

If the engine speed values increase equivalent value of the sound pressure level and instantaneous peak sound pressure level are also raised (Fig. 4 and 5) - for LAeq increase range is $3-44 \%$ (depends from the working point), for LCpk such range is $4-33 \%$. It means that the intensity of the dynamic processes taking place in internal combustion engines rises and level of the energy release from the process is transferred by the block material structure.

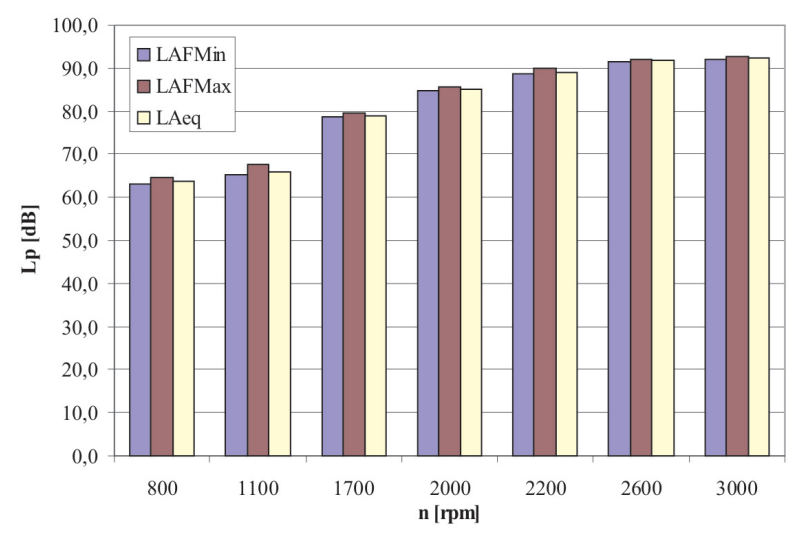

Fig. 4. The equivalent acoustic pressure level (LAeq) changes for different engine speeds

Rys. 4. Równoważny poziom ciśnienia akustycznego (LAeq) dla różnych prędkości obrotowych silnika

Observing the mean point estimator of the vibration accelerations one can find that there is a strict function relation between the engine speed increase and the change of the above point measure (Fig. 6). The mean value, obtained for a combustion process, increases when engine speed rises,

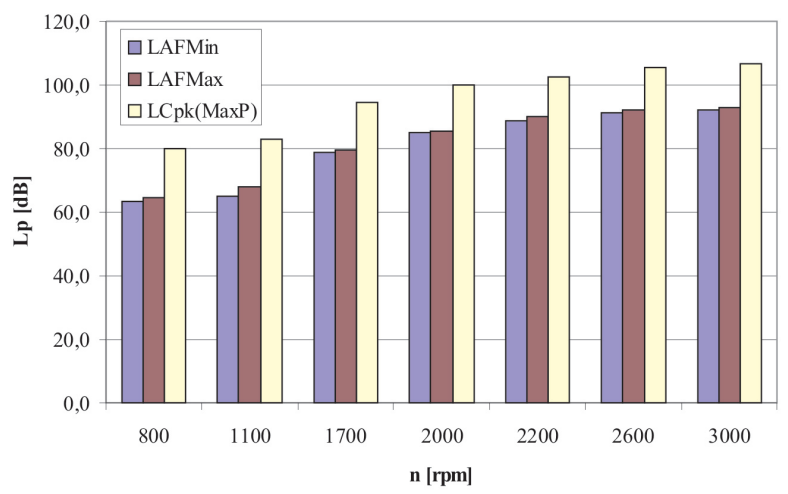

Fig. 5. LCpk(MaxP) acoustic pressure level changes for different engine speeds

Rys. 5. Poziom ciśnienia akustycznego LCpk(MaxP) dla różnych prędkości obrotowych silnika analogowych i cyfrowych, po czym zamieniono je z postaci analogowej w cyfrową. Tak uzyskane sygnały cyfrowe były kierowane do komputera celem ich zapisu w jego pamięci masowej. Zarejestrowane wszystkie przebiegi czasowe sygnałów pomiarowych poddano selekcji czasowej, w ramach której powyższe sygnały podzielono na sekwencje zawierające pojedyncze cykle robocze silnika spalinowego.

\section{Analiza sygnału cyfrowego}

Pierwsza część analizy sygnału pomiarowego dotyczyła określenia poszczególnych przedziałów przebiegów czasowych całego sygnału, związanych z wybranymi grupami procesów dynamicznych zachodzących w silniku. W następnym kroku tak uzyskane przebiegi sygnału podzielono na fragmenty związane z określonym procesem. Fragmenty przebiegów związane z procesem spalania, po ocenie sygnału w dziedzinie czasu, poddane były analizie w dziedzinie amplitud, na podstawie której dokonano wyboru kierunku diagnostycznego i estymatorów punktowych procesu, które umożliwiały uzyskanie najważniejszych informacji diagnostycznych o procesie.

Jeżeli wzrasta prędkość obrotowa silnika, zwiększają się wartości poziomu ciśnienia akustycznego i chwilowego szczytowego poziomu niniejszego parametru (rys. 4 i 5) dla LAeq wzrost zawiera się w przedziale 3-44\% (zależnie od punktu pracy silnika), a dla LCpk w przedziale 4-33\%. Oznacza to, iż wzrasta wówczas intensywność procesów dynamicznych przebiegających w silniku spalinowym, a poziom emisji energii $\mathrm{z}$ procesu jest przekazywany przez strukturę materiału kadłuba.

Obserwując przebieg zmian estymatora punktowego wartości średniej przyspieszeń drgań, można zauważyć, iż istnieje ścisła zależność funkcyjna pomiędzy wzrostem prędkości obrotowej silnika a zmianą powyższej miary punktowej (rys. 6). Wartość średnia uzyskana dla procesu spalania wzrasta wraz ze wzrostem prędkości obrotowej, niezależnie od kierunku rejestracji sygnału. Najwyższe jej wartości uzyskano dla kierunku Z (poza n = 800 i 1100 obr/min).

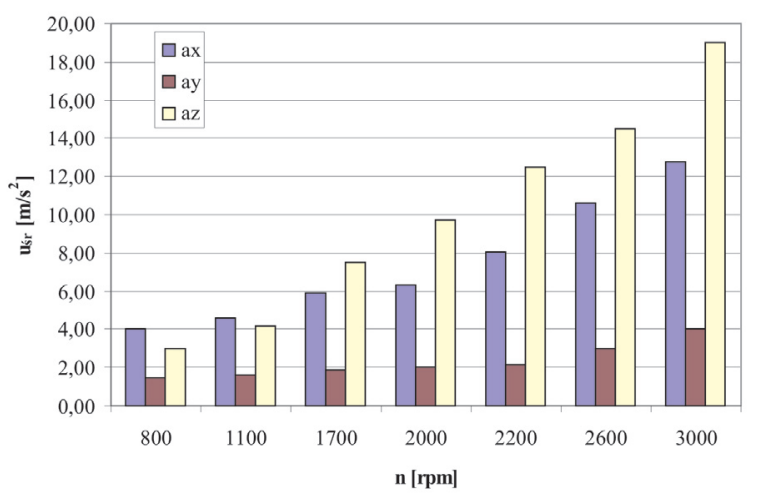

Fig. 6. Mean vibration acceleration values for $\mathrm{X}, \mathrm{Y}$ and $\mathrm{Z}$ dimensions and different engine speeds

Rys. 6. Wartość średnia przyspieszeń drgań w kierunku X, Y i Z dla różnych prędkości obrotowych silnika 
no matter what measurement dimension is considered. The highest values were obtained for $\mathrm{Z}$ dimension (except $\mathrm{n}=$ 800 and $1100 \mathrm{rpm}$ ).

Assessment of the RMS $=\mathrm{f}(\mathrm{n})$ function gives more reliable point estimator for diagnostic of the combustion process changes in CI turbocharged combustion engines (Fig. 7). The highest amplitude values that correlate with analyzed dynamic process and sensitivity were given for $\mathrm{Z}$ direction and the functional relation was kept for all research engine speeds.

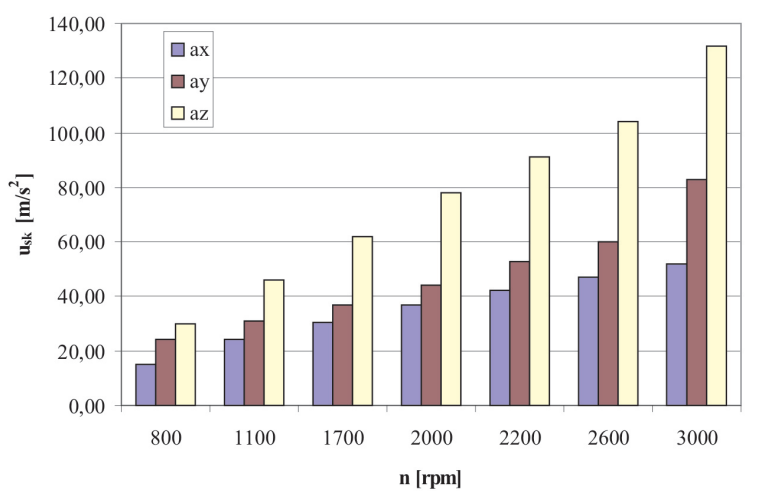

Fig. 7. RMS vibration acceleration values for $\mathrm{X}, \mathrm{Y}$ and $\mathrm{Z}$ dimensions and different engine speeds

Rys. 7. Wartości skuteczne RMS (Root Mean Square) przyspieszeń drgań w kierunku X, Y i Z dla różnych prędkości obrotowych silnika

Comparing such results with the peak and peak-topeak values for the combustion process time run sections it is obvious the above two dimensional point measures of the vibration accelerations have the highest sensitivity for combustion process changes in the relation with the engine speed factor (Fig. 8-9). One-way behaviour of such estimators, specified correlation between both parameters and the trend of their changes make these parameters reliable for a diagnostic system application.

Comparing of all point measures taken into consideration for a $\mathrm{Z}$ dimension one can perceive the peak and peak-to-peak

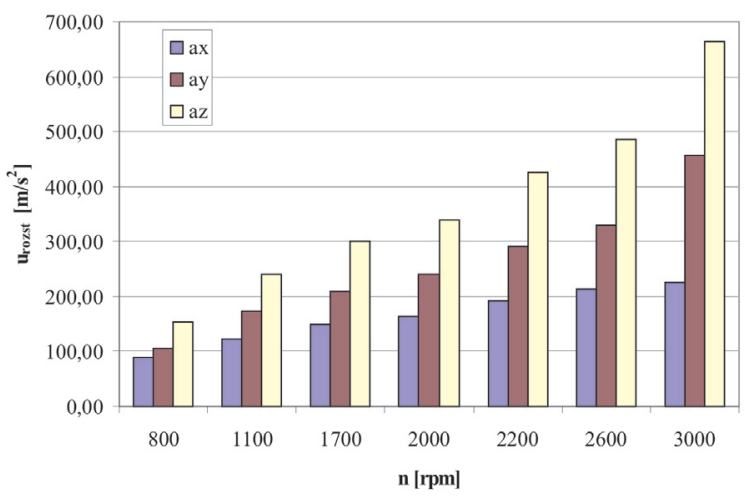

Fig. 9. Peak-to-peak vibration acceleration values for $\mathrm{X}, \mathrm{Y}$ and $\mathrm{Z}$ dimensions and different engine speeds

Rys. 9. Wartość międzyszczytowa przyspieszeń drgań w kierunku $X, Y$ i Z dla różnych prędkości obrotowych silnika
Analiza funkcyjna RMS = f(n) wskazuje, iż niniejszy estymator punktowy jest bardziej wiarygodny dla diagnostyki zmian zachodzących w procesie spalania w doładowanych silnikach ZS (rys. 7). Najwyższe wartości amplitudowe skorelowane $\mathrm{z}$ analizowanym procesem dynamicznym oraz wrażliwość metody na rozpatrywany proces odnotowano dla kierunku Z, które to relacje funkcyjne miały miejsce dla wszystkich badanych prędkości obrotowych.

Przy porównaniu powyższych wyników z wartościami szczytowymi i międzyszczytowymi fragmentów przebiegów

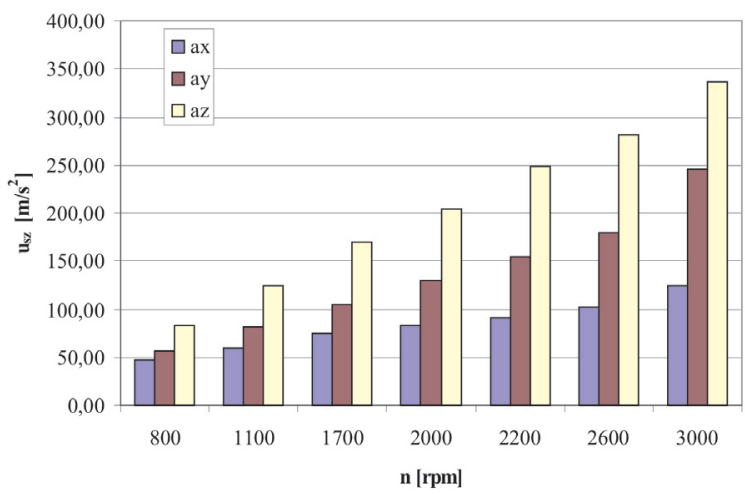

Fig. 8. Peak vibration acceleration values for $\mathrm{X}, \mathrm{Y}$ and $\mathrm{Z}$ dimensions and different engine speeds

Rys. 8. Wartość szczytowa przyspieszeń drgań w kierunku X, Y i Z dla różnych prędkości obrotowych silnika

czasowych reprezentujących proces spalania, oczywiste jest, iż to właśnie te dwie wymiarowe miary punktowe przyspieszeń drgań charakteryzowały się największą wrażliwością na zmiany w tym procesie w odniesieniu do wskaźnika prędkości obrotowej silnika (rys. 8-9). Jednokierunkowe zmiany powyższych estymatorów, określona relacja między tymi parametrami i kierunek zmian czynią te parametry wiarygodnymi do zastosowania w systemie diagnostycznym.

Analiza porównawcza wszystkich rozpatrywanych miar punktowych dla kierunku Z wskazuje, iż wartości: szczytowa i miedzyszczytowa są najbardziej wrażliwe na zmiany w pro-

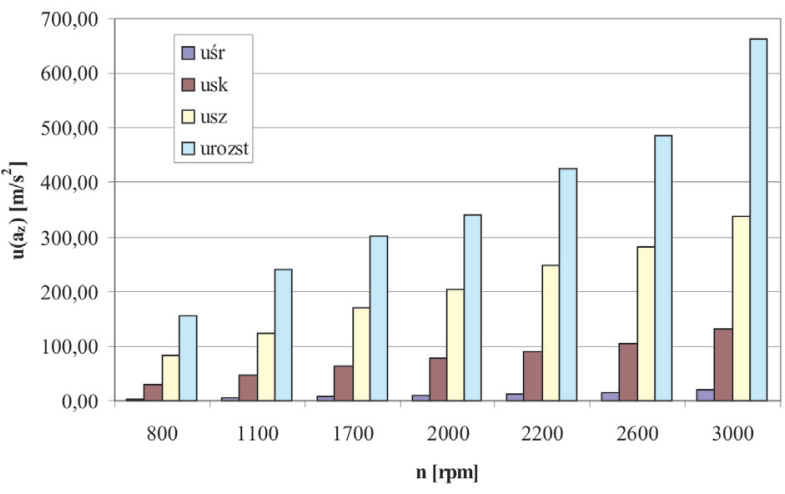

Fig. 10. Changes of the vibration acceleration point measures for $Z$ dimension and different engine speeds

Rys. 10. Zmiany wartości miar punktowych przyspieszeń drgań w kierunku $Z$ dla różnych prędkości obrotowych silnika 
values are the most sensitive measures for combustion process changes resulting from engine speed increase (Fig. 10). That means also the incorrect processes that might appear in the normal combustion engine operation will be unequivocally detected and described.

Analysis of the divided combustion process sections were performed also in the frequency domain (Fig. 11-17). RMS values were taken into consideration to point at the power changes that occur during increase of the engine speed parameter.

RMS value can be computed in the frequency domain, using Parseval's theorem. For a sampled signal [6-9]:

where:

$$
\sum_{n} x^{2}(t)=\frac{\sum_{n}|X(f)|^{2}}{n}
$$

$$
\mathrm{X}(\mathrm{f})=\operatorname{FFT}[\mathrm{x}(\mathrm{t})]
$$

and $\mathrm{n}$ is a number of $\mathrm{x}(\mathrm{t})$ samples.

In the result, the RMS computed in the time domain is the same as in the frequency domain:

$$
\begin{aligned}
\mathrm{u}_{\mathrm{sk}} & =\sqrt{\frac{1}{\mathrm{n}} \sum_{\mathrm{n}} \mathrm{x}^{2}(\mathrm{t})}=\sqrt{\frac{1}{\mathrm{n}^{2}} \sum_{\mathrm{n}}|\mathrm{X}(\mathrm{f})|^{2}}= \\
& =\sqrt{\sum_{\mathrm{n}}\left|\frac{\mathrm{X}(\mathrm{f})}{\mathrm{n}}\right|^{2}}
\end{aligned}
$$

Observations of the RMS spectra runs in the conditions of different engine speeds show the quality and quantity changes in the shape and amplitude values of the RMS values. The amount of the energy release obtained in the process is dependent on the engine speed increase, but the representation of the dynamic process is visible in the specified frequency values.

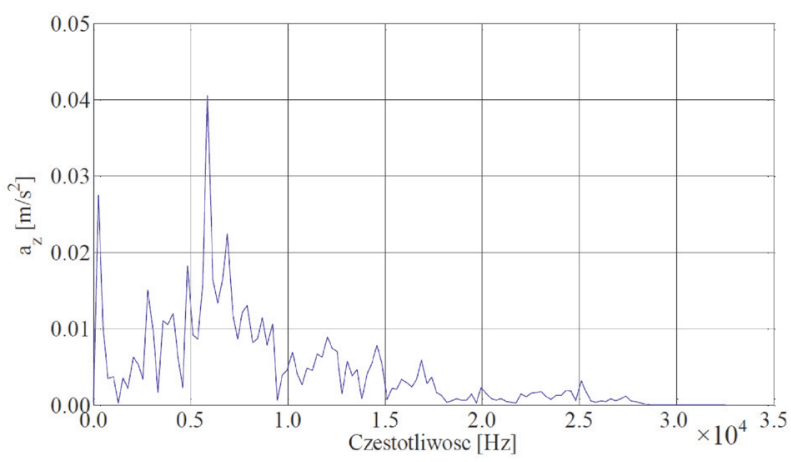

Fig. 13. RMS spectrum run of vibration acceleration in the $\mathrm{Z}$ dimension for $\mathrm{n}=1700 \mathrm{rpm}$

Rys. 13. Charakterystyka częstotliwościowa wartości skutecznej przyspieszeń drgań w kierunku Z dla $n=1700$ obr $/$ min

Identification of the quantity RMS value changes as a result of the process alterations is possible when one states the frequency range for each dynamic phenomenon. In this case we see such RMS value changes in the range 2900-6800 $\mathrm{Hz}$. The high relative change of the RMS values according to cesie spalania, wynikające ze wzrostu wskaźnika prędkości obrotowej (rys. 10). Oznacza to, iż w przypadku pojawienia się nieprawidłowości podczas normalnej pracy silnika będą one jednoznacznie wykryte i określone.

W ramach pracy wykonano ponadto analizę fragmentów sygnałów od spalania w dziedzinie częstotliwości (rys. 11-17). Wartości RMS uwzględniono, aby przedstawić zmiany energetyczne występujące wraz ze wzrostem parametru prędkości obrotowej silnika.

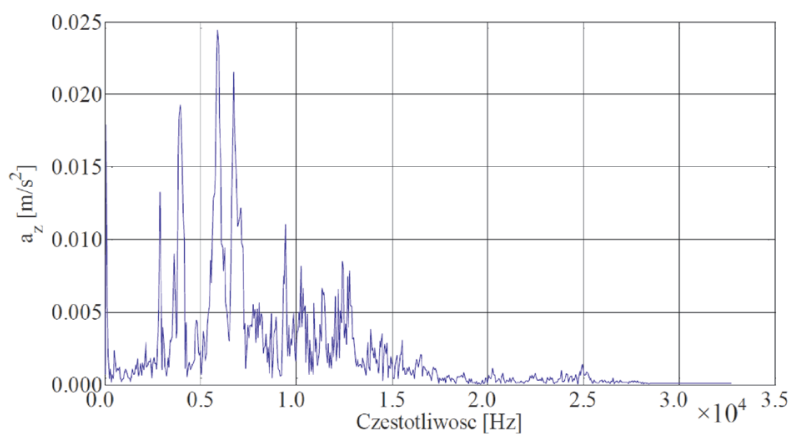

Fig. 11. RMS spectrum run of vibration acceleration in the $\mathrm{Z}$ dimension for $\mathrm{n}=800 \mathrm{rpm}$

Rys. 11. Charakterystyka częstotliwościowa wartości skutecznej przyspieszeń drgań w kierunku Z dla $n=800 \mathrm{obr} / \mathrm{min}$

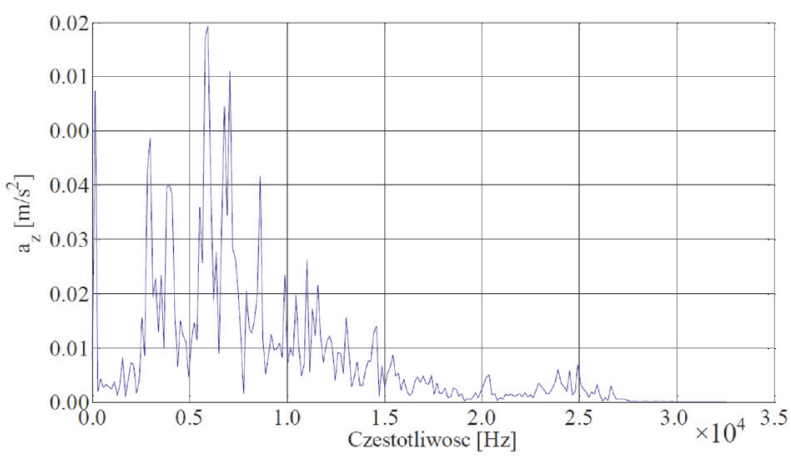

Fig. 12. RMS spectrum run of vibration acceleration in the $Z$ dimension for $\mathrm{n}=1100 \mathrm{rpm}$

Rys. 12. Charakterystyka częstotliwościowa wartości skutecznej przyspieszeń drgań w kierunku Z dla $n=1100 \mathrm{obr} / \mathrm{min}$

Wartość skuteczna może być wyznaczona na podstawie teorii Parsevala. Dla próbkowanego sygnału [6-9] uzyskuje się wzór (5) oraz wzór (6), gdzie n stanowi liczbę próbek x(t).

W wyniku tego wartość RMS, wyznaczona w dziedzinie czasu, ma taką samą postać dla dziedziny częstotliwości wzór (7).

Analiza przebiegu charakterystyk częstotliwościowych dla RMS dla różnych prędkości obrotowych silnika wskazuje na jakościowe i ilościowe zmiany w kształcie i wartościach amplitudowych RMS. Ilość wydzielonej w procesie energii zależy od wzrostu prędkości obrotowej, lecz reprezentacja procesu dynamicznego jest widoczna w uzyskanych określonych wartościach częstotliwości.

Ilościowe określenie zmian wartości RMS będących wynikiem zmian w procesie jest możliwe wówczas, gdy 


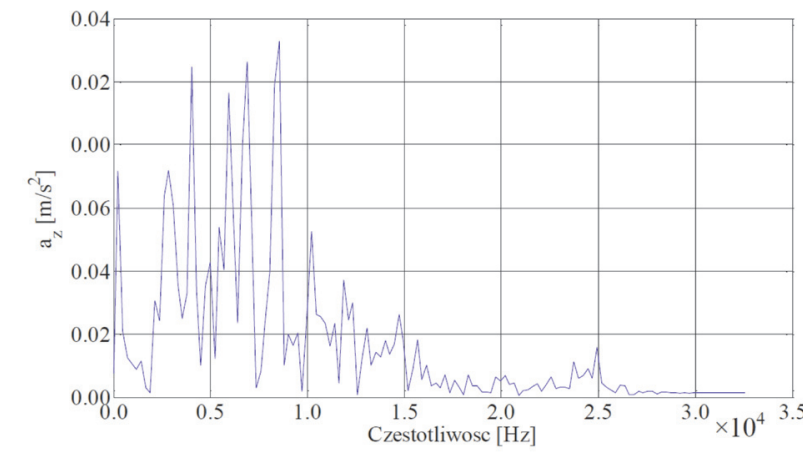

Fig. 14. RMS spectrum run of vibration acceleration in the $\mathrm{Z}$ dimension for $\mathrm{n}=2000 \mathrm{rpm}$

Rys. 14. Charakterystyka częstotliwościowa wartości skutecznej przyspieszeń drgań $w$ kierunku $Z$ dla $n=2000 \mathrm{obr} / \mathrm{min}$

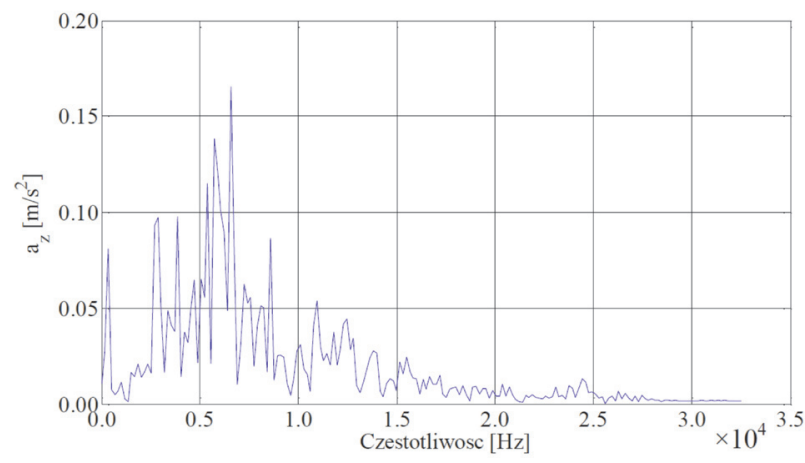

Fig. 16. RMS spectrum run of vibration acceleration in the $\mathrm{Z}$ dimension for $\mathrm{n}=2600 \mathrm{rpm}$

Rys. 16. Charakterystyka częstotliwościowa wartości skutecznej przyspieszeń drgań w kierunku Z dla $n=2600 \mathrm{obr} / \mathrm{min}$

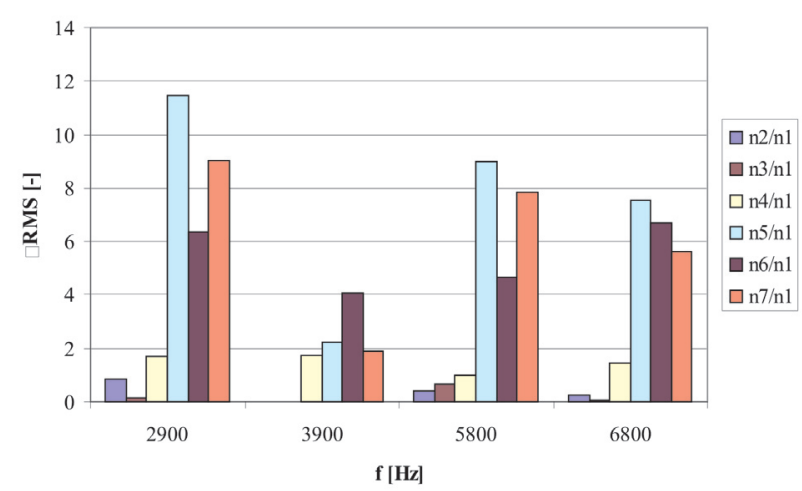

Fig. 18. Relative change of the RMS values for spectra runs and different engine speeds

Rys. 18. Względna zmiana wartości skutecznej dla charakterystyk częstotliwościowych i różnych prędkości obrotowych silnika

engine speeds point was obtained. It was rising when the engine speed was increased $(\delta \mathrm{RMS}=0.38-11.49)-$ Fig. 18 .

\section{Conclusions}

A growing impact of the combustion engines on the environment substantially influenced the design process and the operation of the engine itself. A little vehicles harmfulness for the environment, expressed by the little toxic compounds

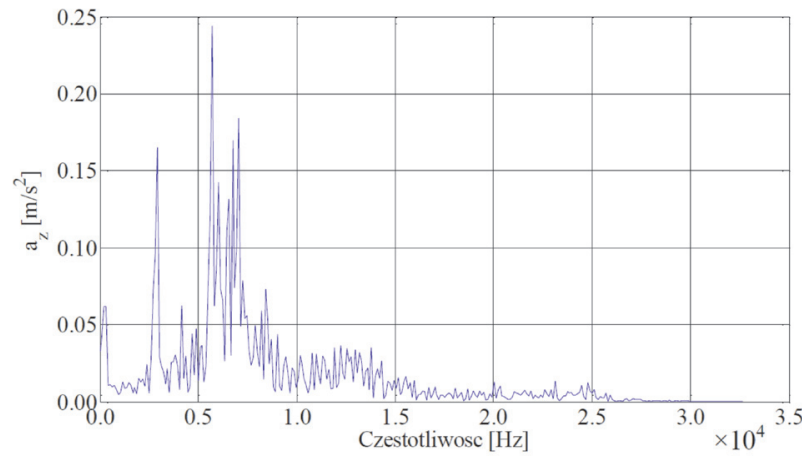

Fig. 15. RMS spectrum run of vibration acceleration in the $\mathrm{Z}$ dimension for $\mathrm{n}=2200 \mathrm{rpm}$

Rys. 15. Charakterystyka częstotliwościowa wartości skutecznej przyspieszeń drgań w kierunku Z dla $n=2200 \mathrm{obr} / \mathrm{min}$

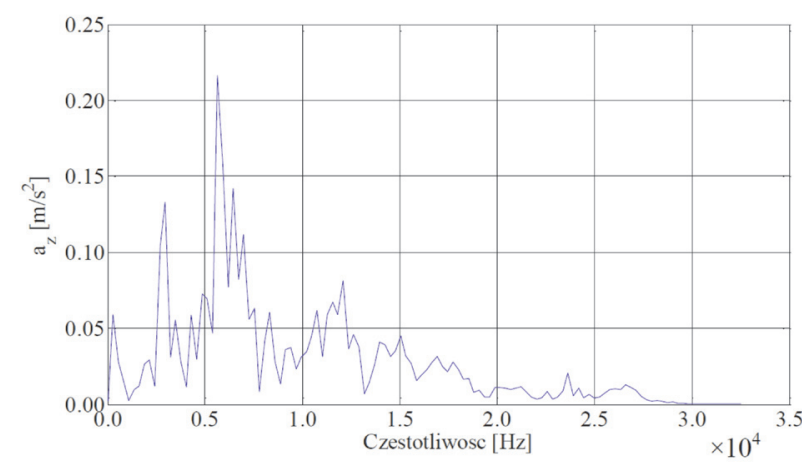

Fig. 17. RMS spectrum run of vibration acceleration in the $\mathrm{Z}$ dimension for $\mathrm{n}=3000 \mathrm{rpm}$

Rys. 17. Charakterystyka częstotliwościowa wartości skutecznej przyspieszeń drgań w kierunku Z dla $n=3000 \mathrm{obr} / \mathrm{min}$

wyznaczy się zakres częstotliwości znamiennych dla każdego zjawiska dynamicznego. Wtedy dostrzega się zmiany wartości RMS w przedziale 2900-6800 Hz. Uzyskano dużą względną zmianę RMS, zgodnie ze zmianą prędkości obrotowej silnika. Wskaźnik powyższy ulegał zwiększeniu przy wzroście prędkości obrotowej $(\delta \mathrm{RMS}=0,38-11,49)$ - rys. 18.

\section{Wnioski}

Rosnące oddziaływanie silników spalinowych na środowisko naturalne wyraźnie wpłynęło na proces konstruowania silników i ich eksploatację. Niewielkie obciążenie środowiskowe, określone przez uzyskanie małych wartości emisji składników szkodliwych spalin, emisji hałasu i zużycia paliwa stanowią wymagania uwzględniane w pierwszej kolejności w procesie projektowania współczesnych silników spalinowych. Wynikiem tej troski o środowisko naturalne jest aplikacja przez państwa rozwinięte gospodarczo coraz bardziej restrykcyjnych regulacji emisji dla pojazdów. Powyższe działania wymuszają postęp techniczny ukierunkowany na uzyskiwanie coraz mniejszych wartości poziomów emisji dla każdego składnika szkodliwego zawartego w spalinach. W następstwie powyższego zastosowano wymagania związane z diagnostyką pokładową silników. Diagnostyka silników z zastosowaniem procesów towarzyszących może stanowić rozwiązanie, dzięki któremu uzyska się wiarygodną kontrolę wszystkich istotnych 
emission, noise emission and the little fuel consumption are the requirements which are put forward first during the design process of the contemporary internal combustion engines. The consequence of the concern with the environment is applying by the industrial developed countries more and more stringent emission regulations for vehicles. These actions extract technical progress in the forward of getting less and less emission levels for each toxic compound of combustion gases. In the aftermath of that, requirements concerning of the on-board diagnostic of engines were applied. Engine diagnostics with the use of the accompanying processes can be the way to obtain the reliable control of all important engine characteristics for the purpose of the OBD requirements application in different groups of sources of a drive.

Obtained results of the vibroacoustic method application helped to assess the relations between main processes changes and the alterations of the chosen point measures as a result of the engine parameters increase. Correlations between these two sorts of parameters in the time, amplitude and frequency domain analyses proved the strict relations between them and helped to find such areas that should be considered in the diagnostic system strategy. The assessment of the measuring signals in the frequency domain enabled to determine the component frequencies included in the time history of the functions. The frequency analysis aimed at the determining of the amplitude values of the vibration signals in the frequency function. Within the frequency analysis, amplitude spectrums of the vibration accelerations were developed for each direction of the signal recording and various working points of the engine. The developing of the amplitude spectrums aimed to determine the frequency range related to the combustion process. The dynamic of the estimator change was calculated and described as well.

\section{Bibliography/Literatura}

[1] Korbicz J., Kościelny J. M., Kowalczuk Z., Cholewa W.: Diagnostyka procesów. WNT, tom 3, Warszawa 2002.

[2] Korbicz J., Kościelny J.: Modelowanie, diagnostyka i sterowanie nadrzędne procesami. Implementacja w systemie DiaSter. WNT, Warszawa 2010.

[3] Lyons R. G.: Wprowadzenie do cyfrowego przetwarzania sygnałów. WKiŁ, Warszawa 1999.

[4] Żółtowski B., Łukasiewicz M.: Diagnostyka drganiowa maszyn. Wydawnictwo Naukowe Instytutu Technologii Eksploatacji Państwowego Instytutu Badawczego, 2012.

[5] www.automex.pl.

[6] www.bksv.com.

[7] www.italiaspeed.com.

[8] www.motor-talk.de.

[9] www.springerprofessional.de.

Prof. Jerzy Merkisz, DSc., DEng. - Professor in the Faculty of Machines and Transport at Poznan University of Technology.

Prof. dr hab. inż. Jerzy Merkisz - profesor na Wydziale Maszyn Roboczych i Transportu Politechniki Poznańskiej.

e-mail: jerzy.merkisz@put.poznan.pl charakterystyk silnika dla aplikacji wymagań diagnostyki OBD w różnych źródłach napędu.

Uzyskane w ramach pracy wyniki zastosowania metody wibroakustycznej umożliwiły ocenę związków między zmianami zachodzacymi w procesach roboczych a zmianami wybranych miar punktowych, jako wynikowymi wzrostu parametrów silnika. Zależności pomiędzy powyższymi dwoma grupami parametrów w dziedzinie czasu, amplitudy i częstotliwości potwierdziły ścisły związek między nimi i były pomocne w znalezieniu obszarów możliwych do rozważenia w strategii systemu diagnostycznego. Analiza sygnałów pomiarowych w dziedzinie częstotliwości umożliwiła wyznaczenie składowych harmonicznych zawartych w przebiegu czasowym funkcji. Analiza częstotliwościowa pozwoliła na wyznaczenie wartości amplitudowych sygnałów drganiowych jako funkcji częstotliwości. W ramach analizy w rozważanej dziedzinie wyznaczono widma amplitudowe przyspieszeń drgań dla każdego z kierunków rejestrowanych sygnałów i różnych punktów pracy silnika. Utworzenie widm amplitudowych umożliwiło określenie zakresu częstotliwości znamiennych dla procesu spalania. Obliczono ponadto dynamikę zmiany estymatora.

\section{Nomenclature/Skróty i oznaczenia}

$\theta \quad$ Object life period/okres życia obiektu technicznego

CI Compression-ignition/zapłon samoczynny

E \{\} Mean operator of the max values of a signal run/operator średniej po maksymalnych wartościach przebiegu sygnału

ICE Internal combustion engine/silnik spalinowy o spalaniu wewnętrznym

LDV Light Duty Vehicle/pojazdy samochodowe o dopuszczalnej masie całkowitej nieprzekraczajacej $3500 \mathrm{~kg}$

Mo Torque/moment obrotowy

n Engine speed/prędkość obrotowa silnika

OBD On-Board Diagnostics/diagnostyka poktadowa pojazdu

OBM On-Board Measurement System/pokładowy system pomiaru emisji spalin dla pojazdu

$\mathrm{p}_{\mathrm{o}} \quad$ Ambient pressure/ciśnienie otoczenia

RMS Root Square Mean/wartość skuteczna

$\mathrm{t}$ Dynamic processes period/okres dynamiczny trwania procesów

T Signal period/okres sygnalu

$\mathrm{t}_{\mathrm{o}} \quad$ Ambient temperature/temperatura otoczenia

$\mathrm{u}(\mathrm{t}, \theta)$ Signal value in the specified time/wartość chwilowa sygnatu

$\mathrm{u} \quad$ Vibroacoustic point measure (śr - mean value, sk - RMS value, sz - peak value, rozst - peak-to-peak value)/wibroakustyczna miara punktowa (śr - wartość średnia, skwartość skuteczna, sz-wartość szczytowa, rozst-wartość międzyszczytowa)

Marek Waligórski, DEng. - Doctor in the Faculty of Machines and Transport at Poznan University of Technology.

Dr inż. Marek Waligórski - adiunkt na Wydziale Maszyn Roboczych i Transportu Politechniki Poznańskiej.

e-mail: marek.waligorski@put.poznan.pl

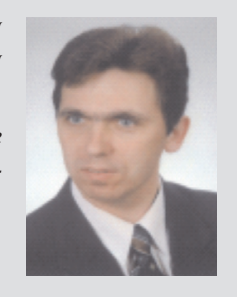

